\title{
Nutritional analysis of three different cultured fishes of Bangladesh
}

\author{
G. M. M. Anwarul Hasan ${ }^{1}$, Dr. Md. Sabir Hossain ${ }^{2}$, Dr. Farha Matin Juliana ${ }^{3}$, Mohajira Begum ${ }^{4}$ \\ Institute of Food Science \& Technology (IFST), Bangladesh Council of Scientific \& Industrial Research(BCSIR), \\ Dr Qudrat-I- Khuda Road, Dhaka, Bangladesh ${ }^{1,4}$ \\ Department of Biochemistry and Molecular Biology, Jahangirnagar University, Savar, Dhaka, Bangladesh ${ }^{2,3}$
}

\begin{abstract}
Nutritional Analysis of the firmed fish species named Pangas (Pangasianodon hypophthalmus), Mrigal (Cirrhinus cirrhosus), Carfu (Cyprinus carpio ) from cultured ponds, wholesale markets and local retail markets were studied in order to evaluate their percentage of moisture, protein, fat, ash. The study focused on the proximate composition and the mean value of moisture was $72.86 \%$ in Pangas, $75.16 \%$ in Mrigal, $73.23 \%$ in Carfu. In case of ash the average value was $1.75 \%$ in Pangas, $2.25 \%$ in Mrigal, 2.23\% in Carfu. The mean value of fat content was $8.17 \%$ in Pangas, $3.56 \%$ in Mrigal and $7.11 \%$ in Carfu. It was observed that the average value of protein were $15.30 \%$ in Pangas, 20.89\% in Mrigal and $18.10 \%$ in Carfu. Each of these three fishes was collected from 9 different sources. We collected these species from Cultured ponds, Wholesale Markets and Local Retail Markets. Highest amount of moisture content was 79.57\% in Pangas (Pangasianodon hypophthalmus), Ash and Fat variation was highest in Pangas (Pangasianodon hypophthalmus) fishes, Protein variation was highest in Mrigal (Cirrhinus cirrhosus).
\end{abstract}

Keywords: biochemical, pangas, mrigal, Carfu, Bangladesh.

\section{INTRODUCTION}

Bangladesh is one of the world's leading inland fisheries producers with a production of 3410254 metric tonnes during 2012-13[1]. They have significant role in nutrition, income, employment and foreign exchange earning of the country. Frozen fish and fisheries products contribute to nearly $5 \%$ of the country's foreign exchange earnings of Bangladesh [2]. Fish is an essential and irreplaceable food item in the rural Bangladeshi diet [3]. Fish have rich source of essential nutrients required for supplementing both infant and adult diets [4]. Fish is predominantly composed of water, lipid, ash and protein and small amounts of carbohydrates and non-protein compounds [59]. Most fish have protein contents between 15 and 30 wt $\%$, fat contents between 0 and $25 \mathrm{wt} \%$, and moisture contents between 50 and $80 \mathrm{wt} \%$ [10].Percentage of composition may change within and between species and also with size, sexual condition, feeding, time of the year and physical activity[11]. So it is important to analyse biochemical composition of protein, fat and ash of fishes that we consume regularly. Although some quality research work have been done [12-15] on the proximate analysis of some commercially important fishes of Bangladesh but no work on Pangus, Mrigal, Carfu that reflects the proximate analysis of fish species with environmental variation. This study was carried out in order to assess the percentage of proximate composition of the three fish species from different environmental condition through laboratory analysis.

\section{MATERIALS AND METHODS}

\section{A. Samples Collection}

The sample of 3 species of fishes were collected from 3 cultured ponds of Comilla, 3 wholesale market of Dhaka, and 3 retail local retail market of Dhaka in the early hours of the day and carried to Food Microbiology section of Institute of Food Science and Technology, Bangladesh Council of Scientific and Industrial Research, Bangladesh. Samples were collected with and transported to laboratory with a sterile aseptic container.

For the analysis following 3 species of fish were selectedPangas (Pangasianodon hypophthalmus), Mrigal (Cirrhinus cirrhosus), Carfu (Cyprinus carpio ). Following parameters were examined in this study Moisture, Ash, Protein, Fat.

\section{B. Sample Preparations}

Samples were taken away from ice box and washed thoroughly with distilled water. After that the samples were cut into very small pieces ( $2 / 3 \mathrm{~g})$ for analysis.

\section{Methods of estimation}

We estimated Moisture and ash contents of the fishes by AOAC method [16] with the help of controlled oven and Muffle furnace.

The estimation of fat content of experimental raw fish were conducted by Bligh and Dryer method [17]. For the determination of the crude protein of fish Micro- Kjeldhal method was used [18].

Calculations:

Calculation of Moisture:

$$
\text { Moisture (\%) }=\frac{\text { Weight loss }}{\text { Original weight of the sample taken }} \times 100
$$


Calculation of Ash:

$$
\text { Ash }(\%)=\frac{\text { Weight of dry samples }}{\text { Original weight of the samples taken }} \times 100
$$

Calculation of Fat:

$$
\text { Fat }(\%)=\frac{\text { Weight of the residus }}{\text { Weight of the samples taken }} \times 100
$$

Calculation of Protein:

$(\%)$ Of Nitrogen $=$ (Titration Reading-Blank Reading $)$ $\times$ Strength Of Acidx100/5×100/Weight Of The Sample in this case empirical factor was 6.25 for the fish

Protein $(\%)=\%$ of Total $\mathrm{N} 2 \times 6$.

\section{III.RESULTS AND DISCUSSIONS}

Tables (1-3) shows Moisture \%, Ash \%, Fat \%, Protein $\%$. of 27 samples of three fishes collected from 9 different environment-

Table 1: Proximate Composition of Pangas (Pangasianodon hypophthalmus) fishes

\begin{tabular}{|l|l|l|l|l|}
\hline Samples & $\begin{array}{l}\text { Moisture } \\
\%\end{array}$ & Ash \% & Fat \% & $\begin{array}{l}\text { Protein } \\
\%\end{array}$ \\
\hline $\begin{array}{l}\text { Comilla Pond-1- } \\
\text { Pangas }\end{array}$ & 72.60 & 1.39 & 8.99 & 13.85 \\
\hline $\begin{array}{l}\text { Comilla Pond-2- } \\
\text { Pangas }\end{array}$ & 75.16 & 1.25 & 7.03 & 15.91 \\
\hline $\begin{array}{l}\text { Comilla Pond-3- } \\
\text { Pangas }\end{array}$ & 69.72 & 1.04 & 9.69 & 16.85 \\
\hline $\begin{array}{l}\text { Wholesale Market- } \\
\text { 1-Pangas }\end{array}$ & 71.22 & 1.26 & 8.36 & 16.78 \\
\hline $\begin{array}{l}\text { Wholesale Market- } \\
\text { 2- Pangas }\end{array}$ & 71.96 & 2.26 & 9.70 & 15.23 \\
\hline $\begin{array}{l}\text { Wholesale Market- } \\
\text { 3- Pangas }\end{array}$ & 72.70 & 1.94 & 8.52 & 14.31 \\
\hline $\begin{array}{l}\text { Local Retail } \\
\text { Market-1- Pangas }\end{array}$ & 69.01 & 2.95 & 8.43 & 16.95 \\
\hline $\begin{array}{l}\text { Local Retail } \\
\text { Market-2-Pangas }\end{array}$ & 73.87 & 1.98 & 7.55 & 14.33 \\
\hline $\begin{array}{l}\text { Local Retail } \\
\text { Market-3-Pangas }\end{array}$ & 79.57 & 1.75 & 5.33 & 13.52 \\
\hline
\end{tabular}

Moisture \% Ash \% Fat \% Protein \%
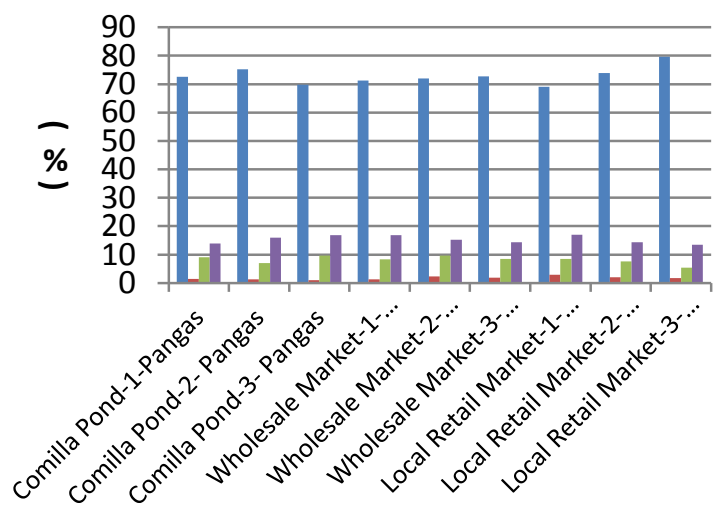

Sample collection point

Fig-1: Variation of moisture, ash, fat and protein among Pangas (Pangasianodon hypophthalmus) fishes which collected from nine different sources.
Table 2: Proximate Composition of Mrigal (Cirrhinus cirrhosus) fishes

\begin{tabular}{|l|l|l|l|l|}
\hline Samples & $\begin{array}{c}\text { Moisture } \\
\%\end{array}$ & Ash \% & Fat \% & $\begin{array}{l}\text { Protein } \\
\%\end{array}$ \\
\hline $\begin{array}{l}\text { Comilla Pond-1- } \\
\text { Mrigal }\end{array}$ & 74.68 & 2.27 & 2.92 & 20.94 \\
\hline $\begin{array}{l}\text { Comilla Pond-2- } \\
\text { Mrigal }\end{array}$ & 71.87 & 2.25 & 4.63 & 21.99 \\
\hline $\begin{array}{l}\text { Comilla Pond-3- } \\
\text { Mrigal }\end{array}$ & 77.35 & 2.54 & 2.49 & 22.43 \\
\hline $\begin{array}{l}\text { Wholesale Market-1- } \\
\text { Mrigal }\end{array}$ & 74.59 & 2.20 & 5.09 & 21.53 \\
\hline $\begin{array}{l}\text { Wholesale Market-2- } \\
\text { Mrigal }\end{array}$ & 72.11 & 2.22 & 2.58 & 20.99 \\
\hline $\begin{array}{l}\text { Wholesale Market-3- } \\
\text { Mrigal }\end{array}$ & 76.74 & 2.75 & 2.29 & 19.83 \\
\hline $\begin{array}{l}\text { Local Retail Market- } \\
\text { 1- Mrigal }\end{array}$ & 76.77 & 1.99 & 4.48 & 20.67 \\
\hline $\begin{array}{l}\text { Local Retail Market- } \\
\text { 2- Mrigal }\end{array}$ & 75.07 & 2.54 & 2.84 & 20.45 \\
\hline $\begin{array}{l}\text { Local Retail Market- } \\
\text { 3- Mrigal }\end{array}$ & 77.26 & 1.53 & 4.74 & 19.20 \\
\hline
\end{tabular}

Moisture \% ash \% $\quad$ Fat \% a Protein \%

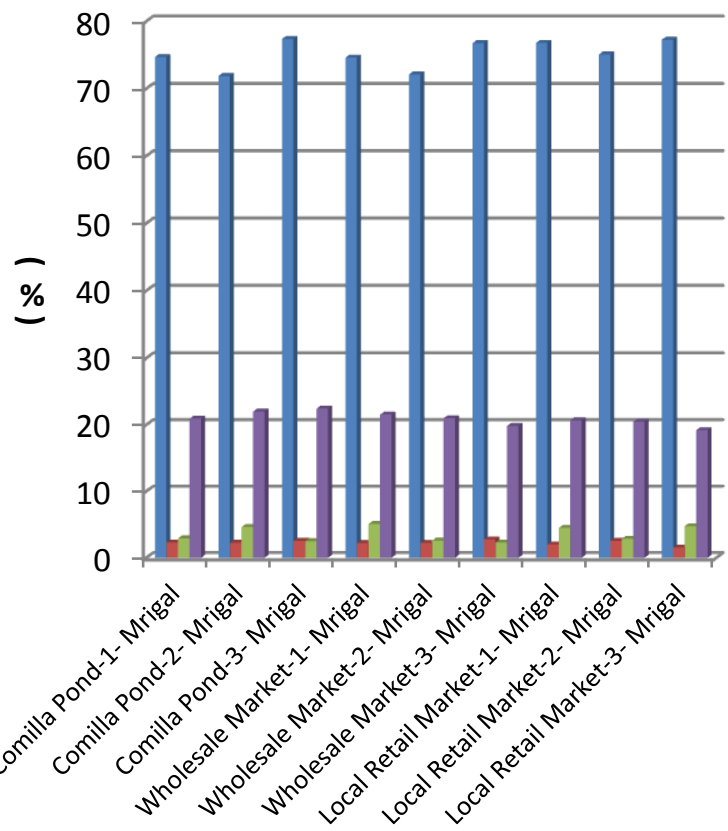

Sample collection point

Fig-2: Variation of moisture, ash, fat and protein among Mrigal (Cirrhinus cirrhosus) fishes which collected from nine different sources.

Table 3: Proximate Composition of Carfu (Cyprinus carpio ) fishes

\begin{tabular}{|l|l|l|l|l|}
\hline Samples & $\begin{array}{l}\text { Moisture } \\
\%\end{array}$ & Ash \% & Fat \% & $\begin{array}{l}\text { Protein } \\
\%\end{array}$ \\
\hline $\begin{array}{l}\text { Comilla Pond-1- } \\
\text { Carfu }\end{array}$ & 76.03 & 1.55 & 6.88 & 15.90 \\
\hline $\begin{array}{l}\text { Comilla Pond-2- } \\
\text { Carfu }\end{array}$ & 70.43 & 2.35 & 7.86 & 19.10 \\
\hline $\begin{array}{l}\text { Comilla Pond-3- } \\
\text { Carfu }\end{array}$ & 73.07 & 2.58 & 8.56 & 17.03 \\
\hline $\begin{array}{l}\text { Wholesale Market- } \\
\text { 1- Carfu }\end{array}$ & 73.88 & 2.26 & 6.90 & 16.92 \\
\hline
\end{tabular}


International Advanced Research Journal in Science, Engineering and Technology

Vol. 2, Issue 9, September 2015

\begin{tabular}{|l|l|l|l|l|}
\hline $\begin{array}{l}\text { Wholesale Market- } \\
\text { 2- Carfu }\end{array}$ & 74.76 & 2.02 & 6.31 & 18.20 \\
\hline $\begin{array}{l}\text { Wholesale Market- } \\
\text { 3- Carfu }\end{array}$ & 75.65 & 2.39 & 6.01 & 16.98 \\
\hline $\begin{array}{l}\text { Local Retail } \\
\text { Market-1- Carfu }\end{array}$ & 75.37 & 2.22 & 8.06 & 17.84 \\
\hline $\begin{array}{l}\text { Local Retail } \\
\text { Market-2- Carfu }\end{array}$ & 69.88 & 2.65 & 6.27 & 21.08 \\
\hline $\begin{array}{l}\text { Local Retail } \\
\text { Market-3- Carfu }\end{array}$ & 70.08 & 2.10 & 7.17 & 19.91 \\
\hline
\end{tabular}

found in the sample collected from Comilla Pond-1 and lowest found in the sample collected from the Local Retail market-2.The finding of the present study are similar to the study of Chatakondi et al [22].

\section{Fat and Protein contents:}

It is observed that fat content of pangas fishes differs from $5.33 \%$ to $9.70 \%$. The highest fat content is found in pangas fishes which are collected from Wholesale Market2 and the lowest amount of fat is found in the fishes which

Moisture \% $\quad$ Ash \% $\quad$ Fat \% $\quad$ - Protein \%
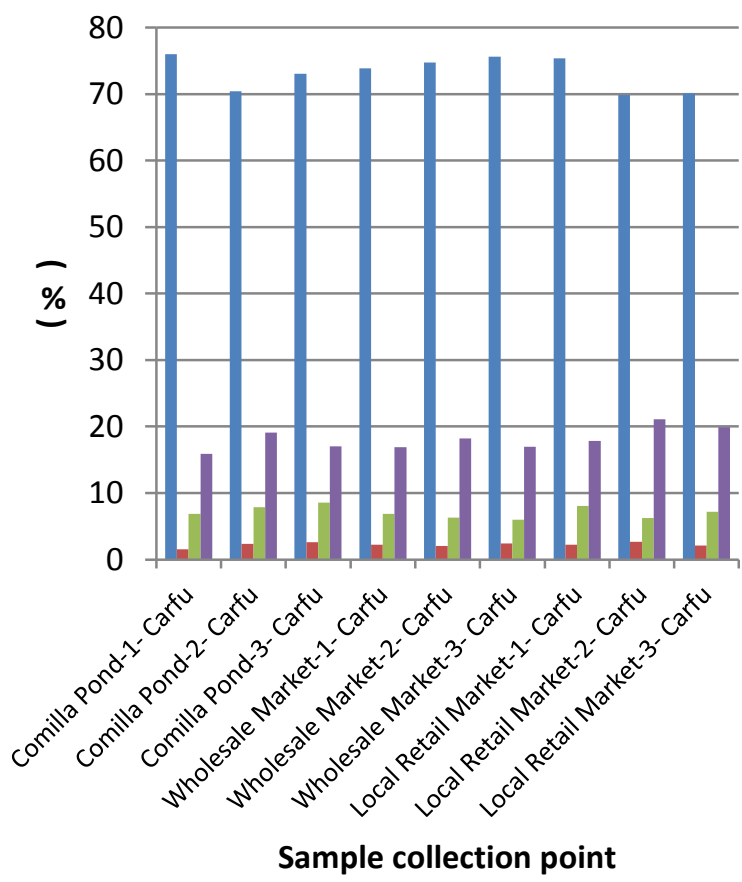

Fig-3: Variation of moisture, ash, fat and protein among Carfu (Cyprinus carpio) fishes which collected from nine different sources.

In case pangas fishes we can see that moisture varies from $69.01 \%$ to $79.47 \%$. Average value of moisture content is $72.86 \%$ which is the near about the finding of Thammapat et al[19] and Karl et al[20].The highest value of moisture among the all Pangas sample found in the sample collected from Local retail market -3 and lowest found in the sample collected from the Local retail Market -1 .

Among the 9 samples of Mrigal, highest moisture found was $77.26 \%$ and lowest was $71.87 \%$.Average value of moisture in Mirgal samples was $75.16 \%$ which is the similar to the finding of The highest value of moisture among the all Mirgal samples found in the sample collected from Local retail market -3 and lowest found in the sample collected from the Comilla Pond -2.Our findings are near to the finding of the study of Mrigal (Cirrhinus cirrhosus) by Manirujjaman et al[21]

The highest value of moisture in all Carfu samples was $76.03 \%$ and lowest value was $69.88 \%$.The average value of moister in all 9 samples of Carfu was $73.23 \%$. The highest value of moisture among the all Carfu samples $1.55 \%$.The average value of ash content in Carfu was Copyright to IARJSET DOI 10.17148/IARJSET.2015.2901 are collected from Local Retail Market-3. The difference between the two values is $4.27 \%$. The difference value is almost double. The examination shows that Pangas fishes from Local Retail Market-3 contains the lowest amount of protein- $13.52 \%$ and Pangas fishes from the Local Retail Market-1 contain highest amount of protein-16.95\%. These results are more or less similar to the findings of Thammapat et al[19] and Karl et al[20].

In the case of Mrigal fishes highest value of fat content is found in the fishes which are collected from Wholesale Market-1 and the value is 5.09 and the lowest amount of fat content is found in the Mrigal fishes which is bought from Wholesale Market-3. The lowest amount of fat content is $2.29 \%$. The difference value is $2.80 \%$. In the case of Mrigal fishes it is found that differences between highest value and lowest value is almost double as like as Pangas fishes. Protein content of Mrigal fishes varies from $19.20 \%$ to $22.43 \%$. Highest value Mrigal fish is collected from Comilla Pond-3 and lowest valued Mrigal fish is collected from Wholesale Market-3. Our findings are near to the finding of the study of Mrigal (Cirrhinus cirrhosus) by Manirujjaman et al[21]

In the regards of fat content of Carfu fishes fat content is differs from $6.01 \%$ to $8.56 \%$ and the Carfu fishes are collected respectively from Wholesale Market-3 and Comilla Pond-3. Highest amount of protein content is $21.08 \%$ which is examined in the sample of Local Retail Market-2- Carfu and lowest amount of protein content is found in the sample of Comilla Pond-1- Carfu-15.90\%. The findings of the present study are similar to the study of Chatakondi et al [22].

\section{Ash contents:}

We got maximum 2.95\% Ash contents in Local Retail market-1 sample among the 9 Pangas samples collected from 9 different environment and lowest amount was 1.04\%.The average value of Ash content in Pangas was $1.75 \%$ this was more or less similar to the result of Thammapat et al[19] and Karl et al[20].

We found $2.75 \%$ highest value of Ash in Wholesale Market -3 of all Mrigal Samples and lowest in local retail Market samples. Lowest value was $1.99 \%$.The average value of Ash content of Mrigal samples was $2.25 \%$. Our findings are near to the finding of the study of Mrigal (Cirrhinus cirrhosus) by Manirujjaman et al[21]

In case of Carfu we found Highest amount of Ash content-2.65\% in Local retail Market and lowest amount of Ash content in Comilla pond -1 sample that was 
$2.23 \%$. The findings of the present study are similar to the study of Schwarz et al [23]

\section{IV.CONCLUSION}

The Present Findings describe the major nutritional composition of three different fish species for three different environmental conditions. Every fish species are reach in protein and fat content so they are suitable for daily diet. So, these species serve as an important source of animal protein and fat for the local people.

\section{REFERENCES}

[1] DoF (Department of Fisheries). 2014. Fishery Statistical Yearbook of Bangladesh 2012-13, Fisheries Resources Survey System (FRSS), Department of Fisheries, Bangladesh.

[2] Ahmed, A.T.A. 2003. Prawn culture. In: Bangladpedia (Ed. Islam, S.). Asiatic Soc. Bangladesh, Dhaka. pp 172-176.

[3] Md. Sarower-E-Mahfuj, M. Belal Hossain and M.H. Minar, 2012. Biochemical Composition of an Endangered Fish, Labeo bata (Hamilton, 1822) from Bangladesh Waters. American Journal of Food Technology, 7: 633-641]

[4] Abdullahi, S.A.; Abolude, D.S. and Ega, R.A. 2001.Nutrient quality of four oven dried freshwatercatfish species in Northern Nigeria. J. Tropical Biosciences, 1(1): 70-76.

[5] Sidwell, V. D., Foncannon, P. R., Moore, N. S., \& Bonnet, J. C. (1974). Composition of the edible portion of raw (fresh or frozen) crustaceans, finfish, and mollusks. I. Protein, fat, moisture, ash, carbohydrate, energy value, and cholesterol. Mar. Fish. Rev, 36(3), 21-35.

[6] Puwastien, P., Judprasong, K., Kettwan, E., Vasanachitt, K., Nakngamanong, Y., \& Bhattacharjee, L. (1999). Proximate composition of raw and cooked Thai freshwater and marine fish. Journal of Food Composition and Analysis, 12(1), 9-16.

[7] Van Pelt, T. I., Piatt, J. F., Lance, B. K., \& Roby, D. D. (1997). Proximate composition and energy density of some North Pacific forage fishes. Comparative Biochemistry and Physiology Part A: Physiology, 118(4), 1393-1398

[8] Mohajira Begum and Maruf Hossain Minar, 2012. Comparative Study About Body Composition of Different SIS, Shell Fish and Ilish; Commonly Available in Bangladesh Trends in Fisheries Research Vol. 1 No. 1 (2012)

[9] Hart, J. L., Tester, A. L., Beall, D., \& Tully, J. P. (1939). Proximate analysis of British Columbia herring in relation to season and condition factor. Journal of the Fisheries Board of Canada, 4(5), 478-490.

[10] Reza Ghaedian, John Neil Coupland, Eric Andrew Decker, David Julian McClements.1998. Ultrasonic Determination of Fish Composition. Journal of Food Engineering Volume 35, Issue 3, February 1998, Pages 323-337.

[11] Weatherley, A.H. and H.S. Gill, 1987. The Biology of Fish Growth. Academic Press, London, Pages: 443

[12] Musa, A. S. M. (2009). Nutritional quality components of indigenous freshwater fish species, Puntius stigma in Bangladesh. Bangladesh Journal of Scientific and Industrial Research, 44(3), 367-370.

[13] Chowdhury, M. F. "A study on the chemical composition and nutritive quality of some fresh-water zeolfishes of Bangladesh." (1981).

[14] Mazumder, M. S. A., Rahman, M. M., Ahmed, A. T. A., Begum, M., \& Hossain, M. A. (2008). Proximate composition of some Small Indigenous fish Species (SIS) in Bangladesh. International Journal of sustainable crop production, 3(4), 18-23.

[15] Nargis, A. (2006). Seasonal variation in the chemical composition of body flesh of koi fish Anabas testudineus (Bloch)(Anabantidae: Perciformes). Bangladesh Journal of Scientific and Industrial Research, 41(3), 219-226.

[16] AOAC (Association of Official Agrichemicals). (1990). Official Methods of Analysis of the Association of Official Agricultural Chemist. HeIritz, K. (Ed.). 15th Ed. Vol.2. Association of Official Analytical Chemists, Inc., Suite 400, 2200 Wilson Boulevard, Arlington, Virginia 22201 USA.p. 685-1298

[17] Bligh E.G. and Dyer W. (1959). Total lipid Extraction and Purification. Can. J. Biochem. Physiol. 37:99-110p.
[18] Pearson D. (1999). Pearson's Composition and Analysis of Foods. University of Reading, Reading, UK.

[19] Pornpisanu Thammapat, Patcharin Raviyan, Sirithon Siriamornpun, 2010.Proximate and fatty acids composition of the muscles and viscera of Asian catfish (Pangasius bocourti), Food Chemistry 122

[20] Horst Karl, Ines Lehmann, Hartmut Rehbein \& Reinhard Schubring,2010.Composition and quality attributes of conventionally and organically farmed Pangasius fillets (Pangasius hypophthalmus) on the German market,International Journal of Food Science and Technology 2010, 45, pg. 56-66

[21] M. Manirujjaman, M.M.H. Khan, Meftah Uddin, Minarul Islam, Matiar Rahman, M. Khatun, Shahangir Biswas, M. A. Islam, et al. "Comparison of Different Nutritional Parameters and Oil Properties of Two Fish Species (Catla catla and Cirrhinus cirrhosus) from Wild and Farmed Sources Found in Bangladesh." Journal of Food and Nutrition Research 2.1 (2014): 47-50.

[22] N. Chatakondi ', R.T. Love11 a, P.L. Duncan ', M. Hayat 2 a,T.T. Chen d, D. A. Powers e, J.D. Weete ', K. Cummins b, R.A. Dunham, 1995. Body composition of transgenic common carp,Cyprinus carpio, containing rainbow trout growth hormone gene Aquaculture 138 (1995) pg.99-109

[23] Frieder J. Schwarz ), Manfred Kirchgessner, Ute Deuringer,1998.Studies on the methionine requirement of carp(Cyprinus carpio L.),Aquaculture 161(1998) pg.121-129 (2010) pg.223-227 